\title{
The Needs Analysis of Four Primary Language Skills in Developing Japanese Teaching Materials for Tourism Purposes
}

\author{
Juju Juangsih, Emzir, \& Yumna Rasyid \\ Universitas Negeri Jakarta \\ E-mail: jujujuangsih@mhs.unj.ac.id; emzir.unj@unj.ac.id;yumna.rasyid@unj.ac.id
}

How to cite (in APA Style): Juangsih, Emzir, \& Rasyid, Y. (2020). The needs analysis of four primary language skills in developing Japanese teaching materials for tourism purposes. Jurnal Pendidikan Bahasa dan Sastra, Vol. 20(2), 185-196. doi: https://doi.org/10.17509/bs_jpbsp.v20i2.33059

Article History: (Received: 22 June 2020, Revised: 1 Aug 2020, Accepted: 1 Sept 2020)

Journal homepage: http://ejournal.upi.edu./index.php/BS_JPBSP

\begin{abstract}
The aim of this study was to analyse the needs of four primary language skills in developing Japanese teaching materials for tourism purposes. Research data was collected by applying questionnaire and interview method. In Tourism and Marketing Management Study Program. The needs analysis result of Japanese teaching materials for tourism showed the average level of percentage ranging from 4 to 5 by applying Likert scale measurement. Based on the questionnaire conducted to 40 participants, speaking skills showed the highest response rate, both from students and lecturer's perception. Listening Skills from student's perception yielded approximately $86 \%$ or an average of 4.3 , while from lecturer's perception yielded $90 \%$ or an average of 4.5. Meanwhile, speaking skills from student's perception reach $95 \%$ response rate or an average of 4.7 , and from lecturer's perception yielded $100 \%$ response rate or an average of 5.0. For the need of reading skills, student's perception showed $86 \%$ response rate or an average of 4.3 , and $80 \%$ or an average of 4.0 for lecturer's perception. Further, the need of writing skills yielded $88 \%$ or an average 4.4 response rate from the students' perception, and $80 \%$ or an average of 4.0 response rate of the lecturer's perception.
\end{abstract}

Keywords: Learning materials; Japanese Language for tourism purpose; four language skills

\section{Analisis Kebutuhan Empat Keterampilan Bahasa Utama dalam Pengembangan Bahan Ajar Bahasa Jepang untuk Keperluan Pariwisata}

\begin{abstract}
Abstrak: Tujuan dari penelitian ini adalah untuk menganalisis kebutuhan empat keterampilan bahasa utama dalam mengembangkan bahan ajar bahasa Jepang untuk tujuan pariwisata. Data penelitian dikumpulkan dengan menggunakan metode kuesioner dan wawancara. Pada Program Studi Manajemen Pariwisata dan Pemasaran. Hasil analisis kebutuhan bahan ajar bahasa Jepang untuk pariwisata menunjukkan tingkat persentase rata-rata berkisar antara 4 sampai 5 dengan menggunakan pengukuran skala likert. Berdasarkan kuesioner yang dilakukan kepada 40 peserta, keterampilan berbicara menunjukkan tingkat respons tertinggi, baik dari persepsi mahasiswa maupun dosen. Keterampilan Menyimak dari persepsi mahasiswa menghasilkan sekitar 86\% atau rata-rata 4,3, sedangkan dari persepsi dosen menghasilkan 90\% atau rata-rata 4,5. Sedangkan keterampilan berbicara dari persepsi mahasiswa mencapai tingkat respons $95 \%$ atau rata-rata 4.7, dan dari persepsi dosen menghasilkan tingkat respons 100\% atau rata-rata 5.0. Untuk kebutuhan keterampilan membaca, persepsi mahasiswa menunjukkan tingkat respon $86 \%$ atau rata-rata 4,3, dan persepsi dosen $80 \%$ atau rata-rata 4,0. Selanjutnya, kebutuhan keterampilan menulis menghasilkan tingkat tanggapan $88 \%$ atau rata-rata 4,4 dari persepsi mahasiswa, dan 80\% atau rata-rata tingkat tanggapan 4,0 dari persepsi dosen.
\end{abstract}

Kata kunci: Materi pembelajaran; Bahasa Jepang untuk tujuan pariwisata; empat keterampilan bahasa 


\section{INTRODUCTION}

Potential students can be developed optimally through planned learning, an active and conducive learning situation; an effective and efficient learning process; and a measurable \& objective learning evaluation. In achieving those goals, wellarranged package of teaching material is required, thus the lecturers and students can use it properly for their teaching-learning process.

Needs analysis is required to investigate the suitable teaching material needed by the students. Hence, the teaching material could match the right learning target and the needs of both students and institutions. This is along with Schares cited by Rasyid (2006, p.99) in his research on identifying student learning needs in European Countries who revealed that the needs of language and its learning must be differed between one student to another; between one group to another. Thus, the students' learning needs is required to be analysed. The information about the students' learning needs is gathered from the students themselves, the lecturers, the institutions implementing language programs and from society.

Teaching Japanese in Tourism and Marketing Management Study Program (here in after referred to as MPP) in Fakultas Pendidikan Ilmu Pengetahuan Sosial (FPIPS) UPI, has been started since 2005. The writer has responsibility of teaching Introduction to Japanese for Tourism Purpose at Level 1 for second term of the MPP Study Program since 2010/2011 school year. This subject is an elective course with 3 credits of Academic Credit System (SKS). At first, to teach the subject, the lecturer uses a book discussing on how to read and write Hiragana and Katakana letters.

In 2015, an evaluation of teaching materials and syllabus of Introduction to Japanese for Tourism Purpose course was conducted. The lecturer has done a needs analysis for students and lecturers in Japanese subject to find out teaching material models they need. It is to make learning Japanese process in MPP Study Program meet the needs of students, lecturers and institutions.

Theories applied in this study are theories of teaching material studied by Brown (1995) and Kawanobe (2020), types of teaching material reported by Ellington (2000) and Rowntree (1998), and about developing teaching material studied by Tomlinson (2003) and Nunan (1988). While theories about language skills were quoted from Krathwoohl and Anderson (2010).

\section{The Concept of Teaching Materials}

The concept of teaching material employed in this paper is taken from Brown and Kawanobe as this following:

Brown (1995, p. 139) defined teaching material as a systematic description of techniques and exercises that will be used in teaching process. The definition is quite broad including lesson plans, textbooks, audio-visual aids, games or various other activities that support the ongoing learning activities in the language class.

Kawanobe (2020) (as in http://www.nit.or.jp/iframes/images/jugy outokyouzai kaiteiban.pdf) added the definition of teaching materials as follows:

“教材とは、一定の目的や目標
を達成するため行われる教
育において使われる素材のこ
とです。目的・目標を達成す
るための内容は教育内容とい
われますが、教材はその教育
内容を児童 ·生徒に習得させ
るための素材です。つまり、
授業を中心とした教育活動を
展開するときに、その目的を
達成するために提示・活用す
る素材ということになりま
す。“

Teaching materials are the materials used in education to achieve a certain purpose or goal. The 
content in achieving the purpose or goal is described as educational content. While teaching material is lesson for children and students to learn educational contents. In other words, it is the material presented and used to achieve learning goals when developing classroomcentred educational activities.

\section{The Types of Teaching Materials}

Ellington (2000) grouped the types of teaching materials based on their shape into seven types, (1) Printed teaching materials and its duplicate such as handouts, student worksheets, self-study materials, group learning materials; (2) Non-projected teaching material display, such as flipcharts, posters, models, and photos; (3) Static projected teaching materials display, such as slides, filmstrips, and others; (4) Audio teaching materials, such as audio-discs, audio tapes, and radio broadcasts; (5) Audio teaching materials linked to static visual material, such as sound slide programs, sound filmstrip programs, tape models, and realia tapes; (6) Video teaching materials, such as television broadcasts, and videotape recordings, and; (7) Computer Teaching Materials, such as Computer Assisted Instruction (CAI) and Computer Based Tutorial (CBT).

Rowntree (1998) emphasized a slightly different perspective from Ellington. Rowntree categorized groups teaching materials into four, they are: (1) Print-based teaching materials, including books, pamphlets, student study guides, tutorial materials, student workbooks, maps, charts, photos, materials from magazines and newspapers, etc.; (2) Technology-based teaching materials, such as audiocassette, radio broadcasts, slides, filmstrips, films, video cassettes, television broadcasts, interactive videos, Computer Based Tutorials (CBT) and multimedia; (3) Teaching materials used for practice or projects, such as science kits, observation sheets, interview sheets, etc., and;
Teaching materials for human interaction needs (especially for distance education), such as telephone, hand phone, video conferencing, etc.

\section{Language Skills}

Language skills are divided into (1) receptive skills, including listening and reading, and (2) productive skills, including speaking and writing.

\section{a) Japanese Listening Skill}

Helgesen (in Ridwan, 2017, p. 27) defined listening as an active process that aims to create meaning of what is heard. Listening requires students to receive and understand the receiving information. Cameron (in Ridwan, 2017, p.27) emphasized that listening is an active use of language to access the meaning conveyed by others. Furthermore, Wilson (in Ridwan, 2017 , p. 27) added that listening is not a mere passive process. Listening is actually very active, through activities that occur in mind. Listeners guess, predict, prove, criticize and interpret.

\section{b) Japanese Speaking Skill}

Speaking is one of productive language skills. According to Iuoma (in Ridwan, 2017, p. 43) speaking is a meaningful interaction between humans. In language activities, a person communicates more verbally through speaking than by other means (for example: writing). Through speaking, people attempt to express their thoughts and feelings to others verbally.

The level of speaking skill to be achieved in this study is that students are able to interact with guests using Japanese in term of providing services.

\section{c) Japanese Reading Skill}

Reading is a complicated process for the readers perform certain level of reconstructing messages delivered by the author in written form (Ridwan, 2017, p.59). In line with that opinion, Robeck and Wilson (in Ridwan, 2017, p. 59) defined the concept of reading as the process of 
translating signs and symbols into meanings and guiding new meanings into the cognitive system of the reader. Reading in this study is limited to only reading Hiragana and Katakana that have been studied in present chapter or in the previous chapters.

\section{d) Japanese Writing Skill}

Writing skill is a complex ability. The author must exert all his abilities, including strengthening aspects of language, the content of writing, and writing techniques, to choose a desired written text. Writers are also required to have various abilities at once, such as what will be written and how to convey it in written from properly.

Cere (in Ridwan, 2017, p.84) defined writing as an essential communication tool. Communication has four elements which are: 1) writing is a form of self-expression; 2 ) writing is a common thing conveyed to the reader; 3) writing is a rule and behaviour; and 4) writing is a way of learning.

While writing skill in this study is limited to Hiragana and Katakana's writing activities whose vocabulary is used in the present chapter.

\section{The Development of Teaching Materials}

The theory used on this paper for the development of teaching material, refers to the theories studied by Jolly and Bolitho (2011); Bell and Gower (2011); Ahmadi (2019); and Nunan (1988). Jolly and Bolitho explained the framework in the development of teaching materials which covered several points, they are: (1) Identifying the need for teaching materials; (2) Exploring the needs; (3) Realization of contextual teaching material; (4) Realization of pedagogical teaching material; (5) Producing teaching materials, and; (6) The implementation of teaching materials to students. Furthermore, Bell and Gower (2011) in Tomlinson (2003, p.109) described the principles of developing teaching material, they are: (1) Flexible; (2) From text to language; (3) Interesting in contents; (4) The language is natural; (5) Using an analytical approach; (6) Emphasis on review; (7) Practicing individually; (8) Applying integrated skills; (9) Using a balanced approach; (10) Increasing the development of students, and; (11) Respecting professionals.

On the other hand, Nunan (1988) in Tomlinson, 2007, p.109) identified the teaching material model into six principles of material development, they are: (1) The material should be clearly related to the curriculum; (2) The material should include things that are authentic in the text and assignments; (3) The material should be a simulation of interaction; (4) The material should encourage students to focus on the formal aspects of language; (5) The material should support students to build their learning abilities and the abilities they learned, and; (6) The material should encourage students to use their ability development outside classroom.

\section{METHOD}

This research consisted of 40 participants from MPP Program Study as its participants for questionnaire. While from the interview, the data gained from two students who were chosen randomly.

\section{Data Collection Technique}

a) Interview

Data of Interview was gathered from both lecturers and students. Interviews were conducted with two randomly selected students and one lecturer of Introduction to Japanese for Tourism Purpose course. The participant in this interview are the third semester students who had taken the Introduction to Japanese for Tourism Purpose course in the previous semester. They are consisted of one male student and one female student. Their average age is around 19. From the lecturers, the participants were female junior lecturers with approximate age of 25 . The interview was employed to investigate the satisfaction of the implemented teaching materials. 


\section{b) Questionnaire}

The questionnaire was provided to 40 students at Level 1 of second semester from MPP Study Program.

\section{RESULTS AND DISCUSSION}

The development of Japanese teaching materials, specifically for tourism needs, begins with analysing the needs of students and lecturers. The material of the questionnaire encompassing four primary language skills (listening, speaking, reading and writing), vocabulary, and grammar. This needs analysis was done by employing questionnaire as instrument. To strengthen the questionnaire data and as additional information, interviews were also conducted with some students and lecturers as its participant. The results of the needs analysis obtained from distributing questionnaires to students and lecturers are as follows.

\section{Duration of Listening Skill}

In question number 3 for listening skill, the first step to examine is related to the duration needed in the teaching process. According to the table below, it can be seen that the time needed to listen is between 34 minutes. That is demonstrated by $93 \%$ response rate of the students perseption, and $40 \%$ response rate of the lecturer perception. The data can be validated through this below table:

Table 1. Duration of Japanese Language Learning Tourism

\begin{tabular}{|c|c|c|c|c|c|}
\hline \multirow{2}{*}{\begin{tabular}{l}
\multicolumn{1}{c}{ Statement } \\
How long do you need \\
to listen to Japanese \\
Conversation Skill \\
䦥<能力?
\end{tabular}} & \multicolumn{2}{|c|}{ Percentage } & \multicolumn{2}{|c|}{ Average } & \multirow[b]{2}{*}{ Criteria } \\
\hline & Student & Lecturer & Student & Lecturer & \\
\hline a. $\quad<2$ minutes & 68 & 30 & 3.4 & 1.5 & $\begin{array}{c}\text { Less agree - } \\
\text { Agree }\end{array}$ \\
\hline b. $2-3$ minutes & 68 & 60 & 3.4 & 3.0 & $\begin{array}{c}\text { Less agree - } \\
\text { Agree }\end{array}$ \\
\hline c. $3-4$ minutes & 93 & 40 & 4.6 & 2.0 & $\begin{array}{c}\text { Agree - Strongly } \\
\text { Agree }\end{array}$ \\
\hline d. $>5$ minutes & 56 & 60 & 2.8 & 3.0 & $\begin{array}{c}\text { Disagree - Less } \\
\text { Agree }\end{array}$ \\
\hline
\end{tabular}

From the table above, it can be concluded that the duration of learning Japanese for tourism needs is as follows; for duration $<2$ minutes, it yielded $68 \%$ response rate with an average of 3.4 from students' perception. While from the lecturer's perception yielded 30\% response rate with an average of 1.5 . For duration 2 3 minutes, student's perception gains $68 \%$ response rate and $60 \%$ with an average of 3.0 response rate of the lecturers' perception. At duration 3-4 minutes, students' perceptions occupy the highest rank of $93 \%$ with an average of 4.6 response rate. While the lecturers' perception got percentage of $40 \%$ with an average of 2.0 response rate. Furthermore, for a duration of $>5$ minutes, students' perceptions got percentage of $56 \%$ with an average of 2.8 . While the lecturers' perception got percentage of $60 \%$ with an average of 3.0.

\section{Listening Skill Materials}

Question number 2 relates to listening skills material. From the results of the table analysis above, three material presentations were obtained which are simple dialogue models, materials related to the context of Japanese daily life, and texts with images. Each of the three materials gains high response rate both from the perception of students and lecturers. Simple 
dialogue model yielded the highest response rate at $92 \%$ based on student perceptions. The following is the data in tabular form.

Table 2. Listening Materials

\begin{tabular}{|c|c|c|c|c|c|}
\hline Statement & Perc & ntage & Ave & rage & \\
\hline $\begin{array}{l}\text { Listening skills } \\
\text { preferences }\end{array}$ & Student & Lecturer & Student & Lecturer & Criteria \\
\hline $\begin{array}{l}\text { a. A simple dialogue model } \\
\text { related to tourism } \\
\text { material accompanied by } \\
\text { vocabulary and } \\
\text { expressions used. }\end{array}$ & 92 & 100 & 4.6 & 5.0 & $\begin{array}{l}\text { Agree - } \\
\text { Strongly } \\
\text { Agree }\end{array}$ \\
\hline $\begin{array}{l}\text { b. Materials related to the } \\
\text { context of Japanese daily } \\
\text { life. }\end{array}$ & 84 & 100 & 4.2 & 5.0 & $\begin{array}{l}\text { Agree - } \\
\text { Strongly } \\
\text { Agree }\end{array}$ \\
\hline $\begin{array}{l}\text { c. Texts that were } \\
\text { supplemented with } \\
\text { images }\end{array}$ & 83 & 100 & 4.1 & 5.0 & $\begin{array}{c}\text { Agree - } \\
\text { Strongly } \\
\text { Agree }\end{array}$ \\
\hline
\end{tabular}

From the data above, it can be concluded that the contents needed in teaching materials of Japanese listening skill for tourism context are: simple dialogue model related to tourism materials followed with glossaries and expressions used. This material content gains $92 \%$ response rate with an average of 4.6 from the students' perception. While from the lecturer's perception, it gains $100 \%$ response rate with an average of 5.0. From the perception of students, material related to the context of Japanese daily life, got a percentage of $84 \%$ with an average of 4.2 and from lecturer's perception got percentage of $100 \%$ with an average of 5.0.

\section{Listening Skill Activities}

There are two activities identified in Japanese listening skills for specific purposes; explaining vocabulary \& phrases to be listened, and completing dialogue. The table showed that both of these activities raise positive responses from students and lecturers. This can be proven by the $80 \%$ response rate from both students' and lecturers' perception. More details are displayed in this following table:

Table 3. Tourism Japanese Language Listening Skill Activities

\begin{tabular}{|c|c|c|c|c|c|}
\hline \multirow{2}{*}{\begin{tabular}{l}
\multicolumn{1}{c}{ Statement } \\
What activities do you need \\
to assist you in learning \\
listening material?
\end{tabular}} & \multicolumn{2}{|c|}{ Percentage } & \multicolumn{2}{|c|}{ Average } & \multirow[b]{2}{*}{ Criteria } \\
\hline & Student & Lecturer & Student & Lecturer & \\
\hline $\begin{array}{l}\text { Explain vocabulary and } \\
\text { expressions related to the text } \\
\text { to be heard/listened. }\end{array}$ & 95 & 80 & 4.7 & 4.0 & $\begin{array}{l}\text { Agree - } \\
\text { Strongly } \\
\text { Agree }\end{array}$ \\
\hline $\begin{array}{l}\text { Completing dialogue in written } \\
\text { form in accordance with the } \\
\text { text being listened/listened to. }\end{array}$ & 91 & 90 & 4.5 & 4.5 & $\begin{array}{l}\text { Agree - } \\
\text { Strongly } \\
\text { Agree }\end{array}$ \\
\hline
\end{tabular}


From the above table, it can be seen that in teaching activities of Japanese listening skill for tourism purposes, explanation of Japanese vocabularies and expressions followed with completing text are required to be done. Student perceptions of vocabulary explaining activities and expressions related to the text listened, gain $95 \%$ or an average of 4.7 response rate. The lecturer's perception showed $80 \%$ response rate or an average of 4.0. While for completing dialogue in written form after the audio of the text is played, the students showed $91 \%$ response rate or an average of 4.5. As for the lecturer's perception got percentage of $90 \%$ or an average of 4.5 .

\section{Listening Skill Input}

Question number 6 is related to speaking skill input. As the data analysis result from the displayed table, there are two materials provided as speaking skill inputs. They are simple dialogue model for tourism purposes and for conversation in Japanese daily life. From the students' and lecturers' responses, simple dialogue model gains above $90 \%$ preference. The displayed table shows the input for Japanese speaking skill:

Table 4. Input of Japanese Language Speaking Tourism Skills

\begin{tabular}{|c|c|c|c|c|c|}
\hline Statement & \multicolumn{2}{|c|}{ Percentage } & \multicolumn{2}{|c|}{ Average } & \multirow[b]{2}{*}{ Criteria } \\
\hline $\begin{array}{l}\text { Input speaking skills that } \\
\text { you like }\end{array}$ & Student & Lecturer & Student & Lecturer & \\
\hline $\begin{array}{l}\text { A simple dialogue model } \\
\text { related to tourism material } \\
\text { accompanied by vocabulary } \\
\text { and expressions used. }\end{array}$ & 95 & 100 & 4.7 & 5.0 & $\begin{array}{c}\text { Agree - Strongly } \\
\text { Agree }\end{array}$ \\
\hline $\begin{array}{l}\text { Materials related to the } \\
\text { context of Japanese daily } \\
\text { life. }\end{array}$ & 72 & 90 & 4.5 & 4.5 & $\begin{array}{l}\text { Less Agree - } \\
\text { Agree }\end{array}$ \\
\hline
\end{tabular}

From the table above, it can be concluded that both students and lecturers need simple dialogue model in teaching learning Japanese speaking skill for tourism purposes. This can be seen from the high percentage of student perceptions of $95 \%$ or an average of 4.7 and the percentage of lecturers' perceptions of $100 \%$ or an average of 5.0. For material related to the context of Japanese daily life, $72 \%$ students responded it as a need or an average of 3.6. While from the lecturer's perception got percentage of $90 \%$ or an average of 4.5 .

\section{Speaking Skill Activity}

Question number 7 concerned about required activities for speaking skills. There are two options of needs in conducting speaking skills activities. They are practicing in front of class or practicing directly in the tourism industry (such as in tourist attractions, guiding tourists, doing tours, etc.). The percentage of both needs is very high, for students $95 \%$, while for lecturers above $80 \%$. Data are presented in this following table: 
Table 5. Tourism Japanese Language Speaking Skill Activity

\begin{tabular}{lccccc}
\hline \multicolumn{1}{c}{ Statement } & \multicolumn{2}{c}{ Percentage } & \multicolumn{2}{c}{ Average } & \\
$\begin{array}{l}\text { What type of activities do } \\
\text { you want to be able to assist } \\
\text { you in learning speaking } \\
\text { material? }\end{array}$ & Student & Lecturer & Student & Lecturer & Criteria \\
\hline $\begin{array}{l}\text { Practice the dialogue model in } \\
\text { front of the class. }\end{array}$ & 95 & 100 & 4.8 & 5.0 & $\begin{array}{l}\text { Agree - } \\
\text { Strongly } \\
\text { Agree }\end{array}$ \\
$\begin{array}{l}\text { Practice directly in the tourism } \\
\text { industry (such as in tourist } \\
\text { attractions, guiding tourists, } \\
\text { doing tours, etc.) }\end{array}$ & 95 & 80 & 4.8 & 4.0 & Agree \\
\hline
\end{tabular}

The table shows that students are strongly agree to implement dialogue practice in front of the class. The same result of $95 \%$ are also shown for practicing directly in the tourism industry. Thus, from the students' perception, both types of activities are what they want to apply in learning speaking material. From lecturers' perception, $100 \%$ agreed for implementing dialogue model practicing in front of the class as their needs to teach Japanese speaking skill. Not as high as students' perception, $80 \%$ lecturers agree that practicing directly in tourism industry is a need in learning speaking material.

\section{Reading Skill Input}

Question number 8 presents information about reading skills input. There are two options related to reading Japanese texts preferred by students. They are simple reading texts and reading texts for tourism purposes. Both students and lecturers perceived those reading skill inputs as their needs in improving Japanese reading skill.

Table 6. Tourism Japanese Reading Skill Input

\begin{tabular}{lcccccc}
\hline \multicolumn{1}{c}{ Statement } & \multicolumn{2}{c}{ Percentage } & \multicolumn{2}{c}{ Average } & Criteria \\
$\begin{array}{lcccccc}\text { Reading Skills Input } \\
\text { Preference }\end{array}$ & Student & Lecturer & Student & Lecturer & \\
\hline $\begin{array}{l}\text { Simple reading text. } \\
\begin{array}{l}\text { Reading text related to the } \\
\text { tourism context. }\end{array}\end{array}$ & 84 & 90 & 4.2 & 4.5 & $\begin{array}{c}\text { Agree - } \\
\text { Strongly Agree } \\
\text { Strongly Agree }\end{array}$ \\
\hline
\end{tabular}

For simple reading text, around $84 \%$ of the students with an average 4.2 considered it as their need in learning Japanese reading skill. While as high as $94 \%$ students with an average of 4.7 responded positively toward reading text related to the tourism context as input for Japanese reading skill. From the lecturers' point of view, approximately $90 \%$ with an average 4.5 strongly agree of the needs for simple reading text. Meanwhile, all participants of lecturers with an average of 5.0 strongly agree of implementing reading text related to the tourism context

\section{Reading Skill Activity}

There are two activities that become the assessment material of students and lecturers in measuring reading skills. Those are activity of reading aloud with correct pronunciation and intonation, and translating every single word into 
Indonesian. The percentage of student perceptions obtained was very high for the two activities mentioned above, but the perception activity of the lecturer in interpreting each word into Indonesian was moderate.

Table 7. Tourism Japanese Reading Skill Activity

\begin{tabular}{lcccccc}
\hline \multicolumn{1}{c}{ Statement } & \multicolumn{2}{c}{ Percentage } & \multicolumn{2}{c}{ Average } & \\
\cline { 1 - 4 } $\begin{array}{l}\text { What kind of activities do } \\
\text { you want to assist you in } \\
\text { learning reading material? }\end{array}$ & Student & Lecturer & Student & Lecturer & Criteria \\
$\begin{array}{l}\text { Reading aloud with correct } \\
\text { pronunciation and intonation. } \\
\begin{array}{l}\text { Translating every single word } \\
\text { into Indonesian }\end{array}\end{array}$ & 95 & 100 & 4.8 & 5.0 & $\begin{array}{c}\text { Strongly } \\
\text { Agree } \\
\text { Less Agree - } \\
\text { Agree }\end{array}$ \\
\hline
\end{tabular}

Based on the table above, the percentage of students' perceptions of loud reading activities with correct pronunciation and intonation was $95 \%$ with an average of 4.8. That is along with $100 \%$ of lecturers who considered reading aloud with correct pronunciation as the need of reading activity in classroom. For translating every single word into Indonesian activity gains 94\% response rate with an average of 4.7 from the students' perspective. On the other hand, only $70 \%$ of the lecturers expect it as their need as teaching reading activity.

\section{Writing Skill Input}

For writing skill input section, there are two components applied as assessments by students and lecturers. They are vocabulary and expressions in the text and conversation related to the text. Both inputs get high positive responds from students' perception

Table 8. Tourism Japanese Writing Skills Input

\begin{tabular}{|c|c|c|c|c|c|}
\hline Statement & \multicolumn{2}{|c|}{ Percentage } & \multicolumn{2}{|c|}{ Average } & \multirow[b]{2}{*}{ Criteria } \\
\hline $\begin{array}{l}\text { Writing skills input } \\
\text { preferences }\end{array}$ & Student & Lecturer & Student & Lecturer & \\
\hline $\begin{array}{l}\text { Vocabulary and expressions } \\
\text { in the text. }\end{array}$ & 94 & 90 & 4.7 & 4.5 & $\begin{array}{c}\text { Agree - } \\
\text { Strongly Agree }\end{array}$ \\
\hline $\begin{array}{l}\text { Conversation related to the } \\
\text { text. }\end{array}$ & 94 & 70 & 4.7 & 3.5 & Agree \\
\hline
\end{tabular}

Vocabulary and expression in the text yielded $94 \%$ as the students' responses. That percentage is as much as their need for conversation related to the text as their input in learning writing skill. However, lecturers show slightly different preference about applying conversation related to text since only $70 \%$ with an average 3.5 who agree with it.

\section{Writing Skill Activity}

The assessment of writing skill activities consists of three components. Those are writing vocabulary in the text with Romaji/Alphabet letters, writing vocabulary in the text with Hiragana letters, and writing vocabulary \& expressions in the text with Hiragana letters accompanied by the correct writing sequence. There is something interesting about these three things, the highest percentage of the answers between students and lecturers is 
different. Most students choose to write Hiragana accompanied by the correct writing method which is got $91 \%$ or an average of 4.5. While the choice of lecturers is to write vocabulary in the text with letters
Romaji/Alphabet which is go $90 \%$ or an average of 4.5. Here is the following table on Tourism Japanese Writing Skills Activities.

Table 9. Tourism Japanese Writing Skill Activities

\begin{tabular}{|c|c|c|c|c|c|}
\hline Statement & \multicolumn{2}{|c|}{ Percentage } & \multicolumn{2}{|c|}{ Average } & \multirow[b]{2}{*}{ Criteria } \\
\hline $\begin{array}{l}\text { What activities do you want to } \\
\text { be able to help you hone your } \\
\text { writing skills? }\end{array}$ & Student & Lecturer & Student & Lecturer & \\
\hline $\begin{array}{l}\text { Writing vocabulary in the text } \\
\text { with Romaji/Alphabet letters }\end{array}$ & 61 & 90 & 3.0 & 4.5 & $\begin{array}{l}\text { Agree - } \\
\text { Strongly } \\
\text { Agree }\end{array}$ \\
\hline $\begin{array}{l}\text { Writing vocabulary in the text } \\
\text { with Hiragana letters }\end{array}$ & 83 & 60 & 4.1 & 3.0 & Less agree \\
\hline $\begin{array}{l}\text { Writing vocabulary \& } \\
\text { expressions in the text with } \\
\text { Hiragana letters accompanied by } \\
\text { the correct writing sequence }\end{array}$ & 91 & 40 & 4.5 & 2.0 & Disagree \\
\hline
\end{tabular}

The table above explains that the percentage of students' perceptions of writing vocabulary in the text with Romaji/alphabet letters got $61 \%$ or an average of 3.0. And the perception of lecturers is actually very high, it got $90 \%$ or an average of 4.5. Then, the percentage of students' perceptions of writing vocabulary in the text with Hiragana letters got $83 \%$ or an average of 4.1. And based on the perception of lecturers got $60 \%$ or an average of 3.0. The percentage of students 'perceptions of writing vocabulary and expressions in the text with Hiragana letters accompanied by a correct writing sequence got $91 \%$ or an average of 4.5 , while based on the lecturers' perceptions got $40 \%$ or an average of 2 .

\section{Four Language Skills}

According to students' perceptions, the most needed language skills out of the four language skills (listening skills, speaking skills, reading skills and writing skills) are speaking skills. Even so, the other skills also cannot be said to have a low percentage.

Table 10. Four Language Skills of Tourism Japanese Language

\begin{tabular}{|c|c|c|c|c|c|}
\hline Statement & \multicolumn{2}{|c|}{ Percentage } & \multicolumn{2}{|c|}{ Average } & \multirow[b]{2}{*}{ Criteria } \\
\hline $\begin{array}{l}\text { The most needed language } \\
\text { skills out of the four language } \\
\text { skills }\end{array}$ & Student & Lecturer & Student & Lecturer & \\
\hline Listening Skills & 86 & 90 & 4.3 & 4.5 & $\begin{array}{c}\text { Agree - Strongly } \\
\text { Agree }\end{array}$ \\
\hline Speaking Skills & 95 & 100 & 4.7 & 5.0 & $\begin{array}{c}\text { Agree - Strongly } \\
\text { Agree }\end{array}$ \\
\hline Reading Skills & 86 & 80 & 4.3 & 4.0 & $\begin{array}{c}\text { Agree - Strongly } \\
\text { Agree }\end{array}$ \\
\hline Writing Skills & 88 & 80 & 4.4 & 4.0 & $\begin{array}{c}\text { Agree - Strongly } \\
\text { Agree }\end{array}$ \\
\hline
\end{tabular}


The table above shows that out of the four language skills, speaking skills occupy the highest percentage, both from students 'perceptions and from lecturers' perceptions. That's because, based on student's perception of listening skills got $86 \%$ or an average of 4.3 , and based on lecturer's perception got $90 \%$ or an average of 4.5. Then for speaking skills, student perceptions got $95 \%$ or an average of 4.7 and lecturers perceptions got $100 \%$ or an average of 5.0. Student perceptions in reading skills got $86 \%$ or an average of 4.3 , and lecturer's perceptions got $80 \%$ or an average of 4.0. In the other hand, writing skills based on student perceptions got $88 \%$ or an average of 4.0

\section{CONCLUSION}

The needs analysis results of the Japanese teaching materials for tourism purposes in Tourism and Marketing Management Study Program - FPIPS UPI showed the average level of response rate ranging from 4 to 5 . This range is obtained from the needs analysis results that determined based on a Likert scale measurement. The needs of Japanese teaching materials for tourism purposes are provided through four primary language skills. Those are provided by focusing on students-centred learning. Those four language skills will be completely integrated during the whole teaching learning process. The learning context will also be directly provided related to the students' learning experiences and their cultural understanding. Japanese learning material for tourism purposes is held through various topics such as types of job in tourism industry, accommodation, culinary, tour guiding, resort and tourist attractions.

The development of the needs analysis refereed to five essential components; 1) identification of problems, which are related to the needs and problems during the Japanese learning process for tourism purposes, 2) identification of priorities related to topics and grammar, 3) identification of abilities related to four language skills of Japanese for tourism purposes, and 4) solutions related to problem solving in the learning process to produce Japanese language learning skills for tourism purposes.

\section{ACKNOWLEDGEMENTS}

I would like to express my gratitude to the lecturers and students of Tourism and Marketing Management Study Program, Universitas Pendidikan Indonesia, who have helped in providing the research data needed. I would also express my gratitude to the Head of Tourism and Marketing Management Study Program for the opportunity to be able to conduct research in classroom.

\section{REFERENCES}

Ahmadi, H. (2019). Principles of Authenticity in Second Language Instructional Materials Development: A Social-constructivist Perspective. Journal of Applied Linguistics and Language Research, 6(3), 132-138.

Bell, J., \& Gower, R. (2011). Writing course materials for the world: A great compromise. Materials development in language teaching, 2, 135-150.

Brown. J.D. (1995). The Elements of Language Curriculum. Boston Massachusetts U.S.A: Heinle \& Heinle Publisher.

Ellington, H. (2000). How to become an excellent tertiary-level teacher. Seven golden rules for university and college lecturers. Journal of Further and Higher Education, 24(3), 311-321.

Intan, N. (2019). Bagi Calon Pendidik Inilah Pengertian dan Jenis-jenis Bahan Ajar. Retrieved 23th April from https://penerbitdeepublish.com/jeni s-bahan-ajar/

Kawanobe、T. (2020). 「授業と教材 教材の正しい理解と活用のため に」. Retrieved 24 th April 2020 from

http://www.nit.or.jp/iframes/image s/jugyoutokyouzai kaiteiban.pdf 
Jolly, D., \& Bolitho, R. (2011). A framework for materials writing. Materials development in language teaching, 107134.

Krathwohl, D.R., \& Anderson, L. W. (2010). Merlin C. Wittrock and the revision of Bloom's taxonomy. Educational psychologist, 45(1), 64-65.

Nunan, D. (1988). The learner-centred curriculum: $A$ study in second language teaching. Cambridge University Press.

Rasyid, Y. (2006). Pengembangan Model Silabus Keterampilan Menulis Babasa Arab di Perguruan Tinggi. Pascasarjana UNJ: Disertasi.

Ridwan, M.H. (2017). Peningkatan Keterampilan Menyimak Berita
Dengan Media Audio Visual Siswa SMP Plus Darussalam Blokagung Banyuwangi. Jurnal Darussalam: Jurnal Pendidikan, Komunikasi dan Pemikiran Hukum Islam,9(1), 32-49.

Rowntree, D. (1998). Assessing the quality of materials-based teaching and learning. Open Learning: The Journal of Open, Distance and E-Learning, 13(2), 12-22.

Tomlinson, B. (2003). Principles and Procedures of Materials Development in Developing Material for Language Teaching. New York: Continum.

(2007). Developing Principal Frameworks for Material Development in Developing Material for Language Teaching. New York: Continum 